\title{
LXXXIV. On embanking 166 acres of marsch land from the sea
}

\section{Edward Dawson Esq.}

To cite this article: Edward Dawson Esq. (1822) LXXXIV. On embanking 166 acres of marsch land from the sea, Philosophical Magazine Series 1, 59:290, 416-417, DOI: 10.1080/14786442208652765

To link to this article: http://dx.doi.org/10.1080/14786442208652765

曲 Published online: 29 Jul 2009.

Submit your article to this journal $₫$

Џ Article views: 3

Q View related articles $\asymp$ 


\section{[ 416$]$}

LXXXIV. On Embanking 166 Acres of Marsh Land from the Sea. By Edward Dawson, Esq. of Aldcliffe Hall, near Lancaster*.

T Aldclife Hall, near Lancaster, Nov. 10, 1820.

Str, - I BEg leave to present a claim to the Society for the Encouragement of Arts, \&ce, for the premium offered in No. 34 of their List of rewards published this year. I transmit the certificates required by the Society, and hope they will be deemed satisfactory.

The inclosure, the consideration of which I have the honour to submit to the Committee, consists of 166 acres, three roods, eight perches of land, known by the name of Aldeliffe Marsh, about two miles distant from the mouth of the river Lune, and one mile from Lancaster. It was, with the exception of alout three acres, swarded over, and has heretofore been attached as a sheep pasture to the different farms on the manor of Aldcliffe; it was estimated at a low rent, as it was in a great measure overflowed by the spring tides, and being intersected by a deep pool, the sheep were frequently surrounded by the water, and consequently lost.

My first operation was, to convey the land waters from this pool into the Lune, which was done by opening for them a wew channel through part of the old inclosures, from nine to twelve feet deep, and 246 yards in length. This cut was walled and covered with stone, and terminates with a hewn culvert of the same material, fonr yards in length, and two feet square.

On the 8th of May last, the embankment was commenced. It runs parallel with the Lune, which is in that part about a mile and a half in breadth at high water. The bighest tides are with in south-west wind, which causes them to set in with considerable violence. The length of the embaukment is 2010 yards; for the first 200 yards at the north (or higher) end, I satisfied myself with a slope of five horizontal to one perpendicular; irr the next 1,400 yards, the slope is 6 to 1 , and where the pool formerly discharged itself, it is for 300 yards 7 to 1 ; the remainder being on high ground, is 5 to $l$; its height averages about 8 feet 6 inches; the greatest perpendicular height being 14 feet 6 inches; the whole of the inside slope is 2 to $\mathrm{l}$. It is entirely composed of sand, with the exception of the deep part, which is formed of clay, the saud being there worn away by the violent reflux of the tide. Its contents are as follows :- 69,456 cubic yards of sand, covered by 53,078 superficial yards of sods

* From the Transactions of the Society for the Encouragement of Arts, Manufictures, and Commerce, for the year 1821. The Society's large Gold Medal was roted to Mr. Dawson for this communication. 
or turf four inches thick, employing 3,824 horses, and 5,843 men, supposing it had been completed in one day.

In order to give employment to the poor of this neighbourhood, I contracted with five different persons; the whole was completed in August, many difficulties retarding it, from the unvsual quantity of rain during the summer months. On the 29th of May, a violent storm of wind raised the tide, and swept away 1800 yards of material, which would have totally discouraged the contractors, who had no property, and could not have sustained the loss, had I not reimbursed them. I am thankful.to say, the high tides in September and October have not made the slightest impression, and the whole of the work carries with it every appearance of stability. I apologize, sir, for the length of this communication; the desire expressed in the rules of the Society, that a detailed account should be given of works of this kind, must plead my excuse. I am, sir, \&c. \&c.

\section{Edward Dawson.}

The equinoctial tides in September were the highest in the last twenty-four years.

\section{CERTIFICATES.}

November 10,1820 .

'This is to certify, that Edward Dawson, of Aldcliffe Hall, has, during the summer of the present year, effectually inclosed and secured from the overflow of the tide, all that tract of land, near Lancaster, called Aldcliffe Marsh.

$$
\text { R. Atkinson, }
$$

One of His Majesty's Justices of the Peace for the County Palatine of Lancaster.

Norember 10, 1820.

I do hereby certify, that Edward Dawson, of Aldeliffe Hall, has, during the summer of the present year, inclosed and effectually secured from the overflow of the sea, all that tract of land, near Lancaster, known by the name of Aldeliffe Marsh.

Thomas Bowes,

Deputy Lieutenant for the County of Lancaster.

LXXXV. On the Smelting of Tin Ores in Cornwull and Devonshire. By John TAYlor, Esq. Treasurer of the Geological Society".

As I am not aware that the treatment of tin ores, or the mode of snelting them, has been recently described, and as the practice is confined to a certain district, it may be acceptable to the Society to have some account of the processes now used in Cornwall and Devon.

* From the Transactions of the Geological Society.

Vol. 59. No.290. June 152\%. $3 \mathrm{G}$ 